University of Nebraska - Lincoln

DigitalCommons@University of Nebraska - Lincoln

U.S. Environmental Protection Agency Papers

U.S. Environmental Protection Agency

2011

\title{
Toxicity and recovery in the pregnant mouse after gestational exposure to the cyanobacterial toxin, cylindrospermopsin
}

\author{
N. Chernoff \\ US EPA, chernoff.neil@epa.gov \\ E. H. Rogers \\ US EPA \\ R. D. Zehr \\ US EPA \\ M. I. Gage \\ US EPA \\ D. E. Malarkey \\ National Institute of Environmental Health Sciences \\ See next page for additional authors
}

Follow this and additional works at: https://digitalcommons.unl.edu/usepapapers

Part of the Civil and Environmental Engineering Commons

Chernoff, N.; Rogers, E. H.; Zehr, R. D.; Gage, M. I.; Malarkey, D. E.; Bradfield, C. A.; Liu, Y.; Schmid, J. E.; Jaskot, R. H.; Richards, J. H.; Wood, C. R.; and Rosen, M. B., "Toxicity and recovery in the pregnant mouse after gestational exposure to the cyanobacterial toxin, cylindrospermopsin" (2011). U.S. Environmental Protection Agency Papers. 82.

https://digitalcommons.unl.edu/usepapapers/82

This Article is brought to you for free and open access by the U.S. Environmental Protection Agency at DigitalCommons@University of Nebraska - Lincoln. It has been accepted for inclusion in U.S. Environmental Protection Agency Papers by an authorized administrator of DigitalCommons@University of Nebraska - Lincoln. 


\section{Authors}

N. Chernoff, E. H. Rogers, R. D. Zehr, M. I. Gage, D. E. Malarkey, C. A. Bradfield, Y. Liu, J. E. Schmid, R. H. Jaskot, J. H. Richards, C. R. Wood, and M. B. Rosen 


\title{
Toxicity and recovery in the pregnant mouse after gestational exposure to the cyanobacterial toxin, cylindrospermopsin
}

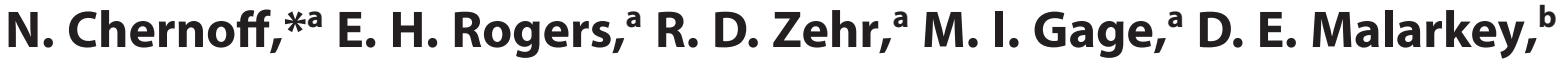 \\ C. A. Bradfield, ' Y. Liu, ${ }^{c}$ J. E. Schmid, ${ }^{a}$ R. H. Jaskot, ${ }^{a}$ J. H. Richards, ${ }^{a}$ \\ C. R. Wood ${ }^{\mathrm{a}}$ and M. B. Rosen ${ }^{\mathrm{a}}$
}

ABSTRACT: Cylindrospermopsin (CYN) is a tricyclic alkaloid toxin produced by fresh water cyanobacterial species worldwide. CYN has been responsible for both livestock and human poisoning after oral exposure. This study investigated the toxicity of CYN to pregnant mice exposed during different segments of gestation. The course of recovery and individual responses to the toxin were evaluated. Adverse effects of CYN were monitored up to 7 weeks post-dosing by clinical examination, histopathology, biochemistry and gene expression. Exposure on gestational days (GD) 8-12 induced significantly more lethality than GD13-17 exposure. Periorbital, gastrointestinal and distal tail hemorrhages were seen in both groups. Serum markers indicative of hepatic injury (alanine amino transferase, aspartate amino transferase and sorbitol dehydrogenase) were increased in both groups; markers of renal dysfunction (blood urea nitrogen and creatinine) were elevated in the GD8-12 animals. Histopathology was observed in the liver (centrilobular necrosis) and kidney (interstitial inflammation) in groups exhibiting abnormal serum markers. The expression profiles of genes involved in ribosomal biogenesis, xenobiotic and lipid metabolism, inflammatory response and oxidative stress were altered $\mathbf{2 4} \mathbf{~ h}$ after the final dose. One week after dosing, gross, histological and serum parameters had returned to normal, although increased liver/body weight ratio and one instance of gastrointestinal bleeding was found in the GD13-17 group. Gene expression changes persisted up to 2 weeks post-dosing and returned to normal by 4 weeks. Responses of individual animals to CYN exposure indicated highly significant inter-animal variability within the treated groups. Copyright $\odot 2010$ John Wiley \& Sons, Ltd.

Keywords: cylindrospermopsin; cyanobacteria; toxicity; mouse; serum chemistries; gene expression

\section{INTRODUCTION}

Cylindrospermopsin (CYN) is a potent tricyclic alkaloid toxin produced by fresh water cyanobacteria that has been associated with toxicity and illness in people after environmental exposures. CYN and several structurally related chemicals are known to be produced by a number of cyanobacterial species that have been identified worldwide. These organisms include Cylindrospermopsis raciborskii in Australia (Ohtani et al., 1992), New Zealand (Stirling and Quilliam, 2001), Thailand (Li et al., 2001a) and the USA (Burns, 2008); Umezakia natans in Japan (Harada et al., 1994); Aphanizomenon ovalisporum in Israel (Banker et al., 1997); Raphidiopsis curvata in China (Li et al., 2001b); Anabaena bergii in Australia (Fergusson and Saint, 2003); and Aphanizomenon flosaquae in Germany (Preussel et al., 2006). The widespread occurrence and increasing range of C. raciborskii (Briand et al., 2004), coupled with its ability to bioaccumulate (White et al., 2006, 2007), indicate that it possesses the potential to cause adverse health effects in cattle (Thomas et al., 1998) and human populations.

The health hazard of CYN to human populations was first noted in 1979 following an illness on Palm Island, Australia, that affected 148 people, a majority of whom required hospitalization. The affected individuals exhibited anorexia, hepatomegaly, abnormal levels of protein, glucose and ketones and, in later stages, blood in the urine, acidotic shock, bloody diarrhea and bleeding mucous membranes (Byth, 1980). Five days prior to the onset of the symptoms, the reservoir serving as the town's drinking water source experienced an algal bloom that was treated with the algicide, copper sulfate. The water that was distributed to the town of Palm Island was subsequently chlorinated as part of the standard water treatment protocol. It was noted that people living in homes not supplied with water from the reservoir did not exhibit the symptoms and the possibility of algal toxicity was suggested (Bourke et al. 1983). Hawkins et al. (1985) identified C. raciborskii as one of the most prevalent species of bloom-forming cyanobacteria in the reservoir at that time and found that administration of this lyophilized algae to mice by intraperitoneal (i.p.)

*Correspondence to: N. Chernoff, US EPA, MD-67, Research Triangle Park, NC 27711, USA.

E-mail: chernoff.neil@epa.gov

aUS EPA, ORD, National Health and Environmental Effects Research Laboratory, Research Triangle Park, NC 27711, USA

${ }^{b}$ National Institute of Environmental Health Sciences, Cellular and Molecular Pathology Branch, Research Triangle Park, NC 27709, USA

'McArdle Laboratory for Cancer Research, University of Wisconsin, 1400 University Avenue, Madison, WI 53711, USA 
injection produced hepatic toxicity as well as toxic effects in other organs. Ohtani et al. (1992) identified the hepatotoxic chemical produced by $C$. raciborskii as CYN and the toxin has now been isolated from different populations of this species. Saker et al. (1999) identified CYN as the probable cause for cattle mortality on a farm in Queensland, and the numerous observations of bioaccumulation, death and developmental toxicity in a variety of organisms have led some workers to suggest that the toxin may be an ecological hazard (see Kinnear et al., 2009).

Mice treated with purified CYN or with CYN-containing cyanobacterial lyophilates exhibit dose-related hepatic and renal damage, as well as adverse effects in other organ systems. The distribution and elimination of CYN has been determined at doses within the lethal range (Norris et al., 2001a) and the half-life was found to be in the range of $12 \mathrm{~h}$. At $12 \mathrm{~h}$ post-dosing, less than $5 \%$ of the dose remained in the liver with much less present in the kidneys or blood. Liver damage, characterized by centrilobular necrosis, is a constant finding in all studies involving the effects of CYN on mammals (Seawright et al., 1999; Bernard et al., 2003; Griffiths and Saker, 2003; Humpage and Falconer, 2003). Kidney damage involving proximal tubule necrosis is often noted, as well as other changes in the basic architecture of the organ (Falconer et al., 1999). Hemorrhages in the lungs (Hawkins et al., 1985; Bernard et al., 2003) and heart (Hawkins et al., 1985; Seawright et al., 1999) have been reported. Comparison of exposure to cellular extracts of $C$. raciborskii and pure CYN revealed differences in the type and severity of toxicity, leading a number of workers to suggest the possibility of other toxins being produced by the cyanobacteria (Falconer et al., 1999; Metcalf et al., 2002; Humpage and Falconer, 2003). It has been hypothesized that CYN may be metabolized to an active compound based on data showing that cytochrome P450 inhibition protects hepatic cell cultures from CYN effects (Runnegar et al., 1995; Humpage et al., 2005); and treatment with the cytochrome P450 inhibitor piperonyl butoxide protected mice from CYN toxicity (Norris et al., 2002), although the active metabolite(s) have not been identified. It should be noted that CYN itself did induce significant gene expression changes in three types of cell cultures not thought to be capable of the metabolic activation of CYN (Bain et al., 2007). Different strains of $C$. raciborskii can produce different toxins, or produce none, and chemical variants of CYN are present in different strains (see Bernard et al., 2003). Two investigators have reported on hepatotoxic effects of cell-free extracts from C. raciborskii strains that did not contain measurable levels of CYN (Fastner et al., 2003; Saker et al., 2003).

Our laboratory has been engaged in a series of studies designed to evaluate the potential developmental toxicity of cyanobacterial toxins in mammals (microcystin-LR, Chernoff et al., 2002; anatoxin-a, Rogers et al., 2005; and CYN, Rogers et al., 2007). In Rogers et al. (2007), the data indicated that maternal exposure to CYN during pregnancy reduced litter size but was not otherwise developmentally toxic when administered on gestational days (GD) 8-12, the major period of organogenesis. When fetuses were exposed later in pregnancy (GD13-17), however, CYN produced a variety of other adverse effects in addition to reduced litter size. At birth, pups were noted with reduced weight and bleeding in the gastrointestinal tract and tail similar to that noted in the pregnant females. All CYN-exposed pups were cross-fostered to control dams but significantly decreased survival was observed. After weaning, a persistent reduced body weight was seen up to $1 \frac{1}{2}$ years after birth. The offspring toxicity data are summarized in Rogers et al. (2007). The data reported here summarize an effort to characterize the adult post-exposure toxicity and subsequent course of recovery after CYN exposure in the post-partum adult females from the 2007 study using a variety of endpoints: gross observations, clinical chemistry markers of hepatic and renal function, histopathology and analysis of gene expression in liver tissue.

\section{MATERIALS AND METHODS}

\section{Animals}

The CD-1 (Swiss-Webster) mice used in the current study were post-parturitional adult females whose litters were used to evaluate the postnatal developmental toxicity of CYN (Study 1 in Rogers et al., 2007). The dams were obtained from Charles River Laboratories (Raleigh, NC, USA) and were singly housed in polycarbonate cages on heat-treated pine shaving bedding in animal rooms with a controlled temperature range $\left(22-26^{\circ} \mathrm{C}\right)$. They were fed commercial rodent chow (Purina Prolab ${ }^{\circledast}$ ) and water ad libitum. Maternal animals treated during two different dosing periods were evaluated: early in gestation (GD8-12) or the end of gestation (GD13-17). GD0 was defined by the presence of a vaginal sperm plug. All studies were conducted after approval by the National Health and Ecological Effects Research Laboratory Institutional Animal Care and Use Committee using the guidelines of the National Research Council (1996).

\section{Compound}

CYN used in these studies was supplied by the Australian Water Quality Center (AWQC), a business unit of the South Australian Water Corporation, Adelaide, Australia. It was purified from bulk cultures of Cylindrospermopsis raciborskii Seenayya Subba Raju using a proprietary method based on that published by Norris et al. (2001b). The purified toxin $\left(\mathrm{C}_{15} \mathrm{H}_{21} \mathrm{~N}_{5} \mathrm{O}_{7} \mathrm{~S}\right.$; CAS no. 14354590-8, molecular weight 415.42) was characterized using nuclear magnetic resonance spectrometry, direct infusion electrospray mass spectrometry and analysis by liquid chromatography using photodiode array and full-scan positive-ion mode mass spectrometric detection. The toxin was shown to be free from organic impurities and present as the sodium salt. The estimated purity was $>98 \%$.

\section{Experimental Design}

Pregnant mice were administered daily i.p. injections of $50 \mu \mathrm{g} \mathrm{kg}^{-1}$ CYN in $0.1 \mathrm{ml}$ distilled water for five days on GD8-12 (42 animals) or GD13-17 (42 animals). The dose was calculated based on the GD7 weight and the quantity of CYN administered was not altered during the course of dosing. Concurrent controls received $0.1 \mathrm{ml}$ distilled water alone on either GD8-12 (26 animals) or GD13-17 (26 animals). Toxicity induced by CYN after i.p injection indicates that the hepatic and renal effects are qualitatively similar to those obtained after oral dosing, although the oral route is less toxic by a $\sim 25$-fold factor (Falconer et al., 1999). The similarity of the observed toxicity to the effects noted in the human population, coupled with the difficulty in obtaining an adequate supply of CYN, was the basis of our choice of the i.p. route for these studies. Dose-response data from the study (data not shown, see Rogers et al., 2007) indicated that $50 \mu \mathrm{g} \mathrm{kg}^{-1}$ per 
day induced effects that were similar to those seen in humans (i.e. hepatic and renal toxicity and gastrointestinal bleeding). Levels of $32 \mu \mathrm{g}$ did not induce these effects and doses higher than $50 \mu \mathrm{g} \mathrm{kg}^{-1}$ per day induced death in the great majority of test animals. Animals were weighed prior to treatment, during the dosing period and on the day they were euthanized. Subsets of animals (two or three controls and three to five CYN-exposed) were euthanized the day following the last dose and on posttreatment days 7 and 14 for both exposures; days 28 and 42 for the GD8-12 exposure, and on days 35 and 49 for the GD13-17 exposures. Blood, liver and kidney samples were obtained at each time point for further analyses. Endpoints measured included maternal weight, clinical signs of toxicity, during and after the dosing period; serum chemistries indicative of hepatic and/or renal function and general homeostasis, histopathology of liver and kidney tissues, and hepatic gene expression after the dosing period.

\section{Blood Collection and Serum Preparation}

Animals were euthanized by $\mathrm{CO}_{2}$, and removed when breathing ceased. Access to the descending aorta was obtained by making $a^{\prime} V^{\prime}$-shaped cut in the abdominal wall and displacing the organs to visualize the vessel just below the diaphragm. Blood was collected from the descending aorta immediately by inserting a $26 \mathrm{G}$ $3 / 8$ inch needle attached to a $1 \mathrm{~cm}^{3}$ syringe into the vessel. The collected blood was transferred to a $4 \mathrm{ml}$ Vacutainer serum separator tube, allowed to clot for approximately $1 \mathrm{~h}$, and spun at $3000 \mathrm{rpm}$ for $10 \mathrm{~min}$ to separate the serum. Serum was transferred to an autoanalyzer cup and stored at $-80^{\circ} \mathrm{C}$.

\section{Serum Chemistries}

Serum clinical chemistry markers of hepatic and renal function and injury were measured using the Konelab Arena 30 Clinical Analyzer (Thermo Clinical Labsystems, Espoo, Finland). Hepatic function was assessed with AAT (alpha-1 antitrypsin), ALP (alkaline phosphatase), ALT (alanine aminotransferase), AST (aspartate aminotransferase), LDH (lactate dehydrogenase) and SDH (sorbitol dehydrogenase). Renal function endpoints were BUN (blood urea nitrogen) and creatinine. Glucose and albumin were measured as markers of general toxicity. All assays were performed using commercially available clinical chemistry kits. LDH, BUN, glucose, ALT, AST and ALP kits were obtained from Thermo Electron Corp., Melbourne, Australia. Creatinine and SDH kits are from Diagnostic Chemicals Ltd, Oxford, CT. Albumin and AAT kits were obtained from DiaSorin Inc. (Stillwater, MN, USA).

\section{Tissue Preparation for Histological Evaluation}

The liver and kidneys were excised, weighed, and examined for visible lesions. Liver tissue samples approximately $3 \mathrm{~mm}$ thick were obtained from both the median and left lobes of 56 animals and fixed in $>10 \times$ volume $10 \%$ neutral buffered formalin (NBF). Both kidneys were collected from the same animals, the right kidney cut longitudinally and the left cross-sectionally, and also fixed in $>10 \times$ volume $10 \%$ NBF. Tissues were placed on a horizontal shaker for at least $18 \mathrm{~h}$ and then transferred to $70 \%$ ethanol for not more than $72 \mathrm{~h}$. Sections of liver and kidney from each animal were evaluated. Tissues were routinely processed, embedded in paraffin, sectioned at approximately $5 \mu \mathrm{m}$, stained with hematoxylin and eosin, and examined histologically. Tissues were examined using an Olympus BX51, with a 7-ocular nosepiece ranging from $100 \times$ to $600 \times$.

\section{Gene Array and Real-time RT-PCR Analysis of Hepatic Tissue}

A tissue sample, adjacent to that collected for histopathology, was obtained from the liver for gene array analysis. The tissue was immediately homogenized in TRI reagent (Sigma-Aldrich, St Louis, MO, USA) and processed through alcohol precipitation on the same day. RNA pellets were then stored at $-80^{\circ} \mathrm{C}$ until further use. Following resuspension in RNase free water, RNA samples were quantified using a NanoDrop ND-1000 spectrophotometer (NanoDrop Products, Wilmington DE), purified through RNeasy spin columns (Qiagen, Valencia, CA, USA), evaluated using a 2100 Bioanalyzer (Agilent Technologies, Santa Clara, CA, USA), and subsequently stored at $-80^{\circ} \mathrm{C}$. Only samples with an RNA Integrity number of at least 8.5 (2100 Expert software, version B.01.03) were included in the study. RNA labeling, microarray hybridization and scanning, and data reduction were done at the EDGE ${ }^{2}$ Program, University of Wisconsin, using a two-channel customspotted microarray developed for evaluation of liver toxicity (see Hayes et al., 2005 for details on generation of arrays and techniques used to obtain the gene array data).

Real-time RT-PCR analysis was performed using genes selected to verify the effects noted by microarray analysis. These analyses were conducted using the same RNA samples utilized for microarray analysis with the addition of either two or three samples per group from the GD13-17 dose group that were included to evaluate treatment recovery at 7, 16, and 28 days post-dosing. Two micrograms total RNA was digested using 2 units DNasel (no. M6101, Promega Corporation, Madison, WI, USA) for $30 \mathrm{~min}$ at $37^{\circ} \mathrm{C}$ followed by $10 \mathrm{~min}$ at $65^{\circ} \mathrm{C}$ in a buffer containing $40 \mathrm{~mm}$ Tris ( $\mathrm{pH} 8.0$ ), $10 \mathrm{~mm} \mathrm{MgSO}_{4}$ and $1 \mathrm{~mm} \mathrm{CaCl}_{2}$. The RNA was then quantified using a Quant-iT RiboGreen RNA assay kit according to the manufacturer's protocol (no. R11490, Invitrogen Corporation, Carlsbad, (A, USA) and approximately $1.5 \mu \mathrm{g}$ RNA reverse transcribed using a High Capacity cDNA Archive Kit according to the provided protocol (no. 4322171, Applied Biosystems, Foster City, CA, USA). Amplification was performed on an Applied Biosystems model 7900HT Fast Real-Time PCR System in duplicate using $25 \mathrm{ng}$ cDNA and TaqMan Universal PCR Master Mix (no. 4304437, Applied Biosystems) in a total volume of $12 \mu \mathrm{l}$. Beta-2-microglobulin (B2m, Entrez no. 12010) was used as an endogenous reference gene. The following TaqMan assays (Applied Biosystems) were included in the study: B2m (no. Mm00437762_m1), Ehhadh (no. Mm00470091_s1), Cyp2b10 (no. Mm00456591_m1), Cyp2E1 (no. Mm00491127_m1), Fabp1 (Mm00444340), Gclc (Mm00802655_m1), Nfe2I2 (Mm00477784_ m1), Rpl6 (Mm01198491_g1), Rps12 (Mm03030276_g1), F10 (Mm00484177_m1), C4a (no. Mn00550309_m1), C9 (Mm00442739_m1) and Hpx (Mm00457510_m1). Fold change was estimated using the $2^{-\Delta \Delta C}$ T method of Livak and Schmittgen (2001).

\section{Data Evaluation}

The weight and clinical chemistry data were analyzed by analysis of variance (ANOVA) using SASversion 9.2 software (SAS Institute Inc., 2008). Means, standard errors and coefficients of variation 
were calculated in Proc Means. In many cases the variances of outcome measures were not homogeneous across the treatment groups; therefore a Box Cox transformation was calculated (SAS Proc Transreg) to stabilize the variance (Box and Cox, 1964). Proc GLM was used to perform one-way ANOVAs on the transformed data across the 10 treatment by day groups. Pairwise $t$-tests were calculated within the ANOVAs to test for differences between the treated and control groups at each time point; a Bonferroni correction was used to adjust for multiple comparisons. Where a direction of change was predicted a priori, a one-sided $t$-test was used; otherwise a two-sided test was used. Levene's test (Levene, 1960) was used to evaluate the statistical significance of the difference in variance between the treated group one day after the last dose and the pool of all other treatment groups. In the array data, gene transcripts that deviated more than 2-fold from control were further evaluated for relevance to canonical pathways and biological functions using Ingenuity Pathways Analysis (Ingenuity Systems, www.ingenuity.com). Heat maps were generated using Eisen Lab Cluster and Treeview software (http:// rana.lbl.gov/EisenSoftware.htm).

\section{RESULTS}

\section{Clinical Findings}

Clinical signs of toxicity are summarized in Table 1. GD8-12 animals were affected earlier and to a greater degree than the GD13-17 group. Maternal weight gain was significantly reduced after the initial dose of CYN in the GD8-12 animals and this effect continued throughout the treatment period (Fig. 1a). After the fifth dose, maternal weights were significantly reduced, but this effect did not persist (Table 2). Vaginal bleeding was observed on GD11 following the third dose of CYN along with reduced activity, blood in the distal area of the tail, and mild to moderate hemorrhage in and around one or both eyes following the fourth dose. Vaginal and/or periorbital hemorrhages were often associated with death before GD17. Mortality and moribidity-required euthanasia initially occurred after the fourth dose on GD12 (8/42 animals). Eight died on GD13 after the fifth dose with an additional five moribund animals euthanized at that time. Single instances of death occurred on GD16 and GD18. Gestational length in treated animals did not differ from controls.

The body weights of the GD13-17 dosed animals were not as severely affected; the only significant weight differences noted were after the second dose (Fig. 1b) and 49 days after the last dose (Table 3). There were no deaths in this group. Intraluminal blood in the gastrointestinal tract of GD13-17 animals was found

in three of four euthanized one day after the last dose and 1 of 5 on the seventh day after the last dose. A single instance of bleeding around the eyes was observed. Treated animals gave birth earlier than controls with $58 \%$ of the CYN animals giving birth by 1:00 p.m. on GD18/PND0 as compared with $31 \%$ of the controls.

No other clinical signs of toxicity were observed in either group after 7 days post-dosing.

\section{Serum Biochemistries and Organ/body Weight Ratios}

The data for the GD8-12 and GD13-17 dose groups are summarized in Tables 2 and 3. The mean levels of three markers of hepatic function (AAT, ALT and AST) were significantly elevated $(P \leq 0.01)$ on the day following the last dose in both the GD8-12
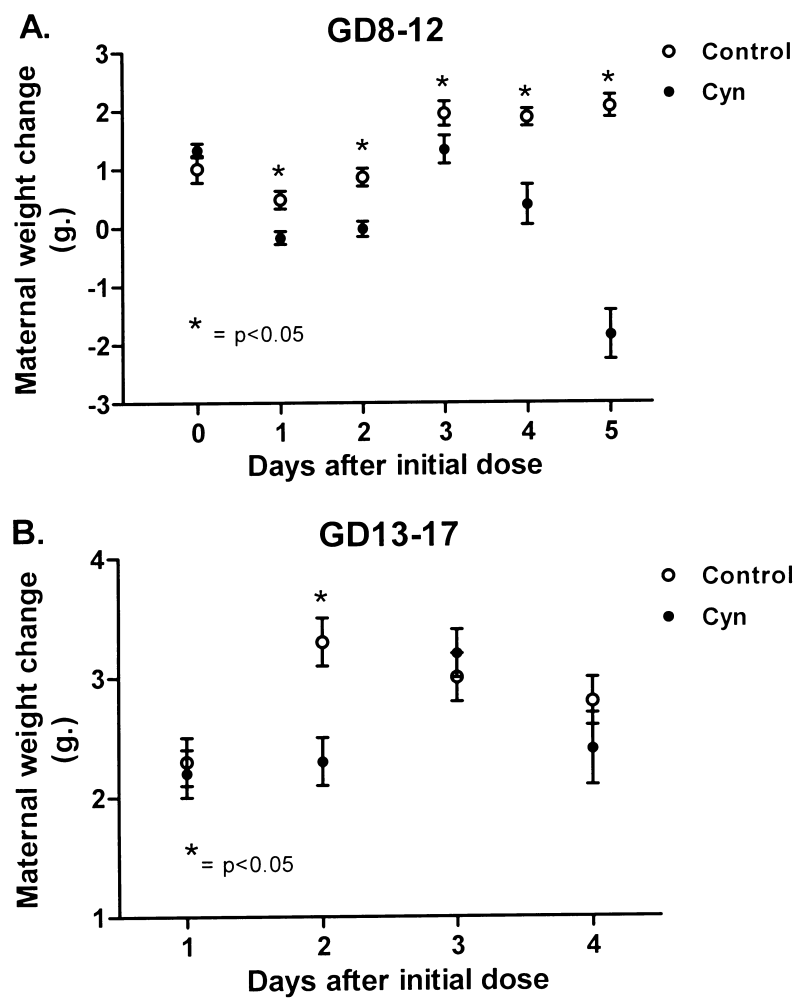

Figure 1. Maternal weight change during cylindrospermopsin administration: (A) GD8-12; (B) GD13-17. Note that animals in the GD13-17 group had given birth after the fifth dose and therefore these data are not shown.

\begin{tabular}{|c|c|c|c|c|c|c|c|}
\hline \multirow[b]{2}{*}{ Exposure } & \multirow[b]{2}{*}{ Treatment } & \multirow[b]{2}{*}{ No. mice } & \multirow[b]{2}{*}{ No. died (\%) } & \multicolumn{4}{|c|}{ Bleeding (no.) ${ }^{a}$} \\
\hline & & & & Vaginal & Orbital & Tail & Gastrointestinal \\
\hline \multirow[t]{2}{*}{ GD 8-12 } & Control & 26 & 0 & 0 & 0 & 0 & 0 \\
\hline & CYN & 42 & $23(55)^{b}$ & 13 & 2 & 2 & 0 \\
\hline \multirow[t]{2}{*}{ GD 13-17 } & Control & 26 & 0 & 0 & 0 & 0 & 0 \\
\hline & CYN & 42 & 0 & 0 & 1 & 0 & $3^{c}$ \\
\hline
\end{tabular}




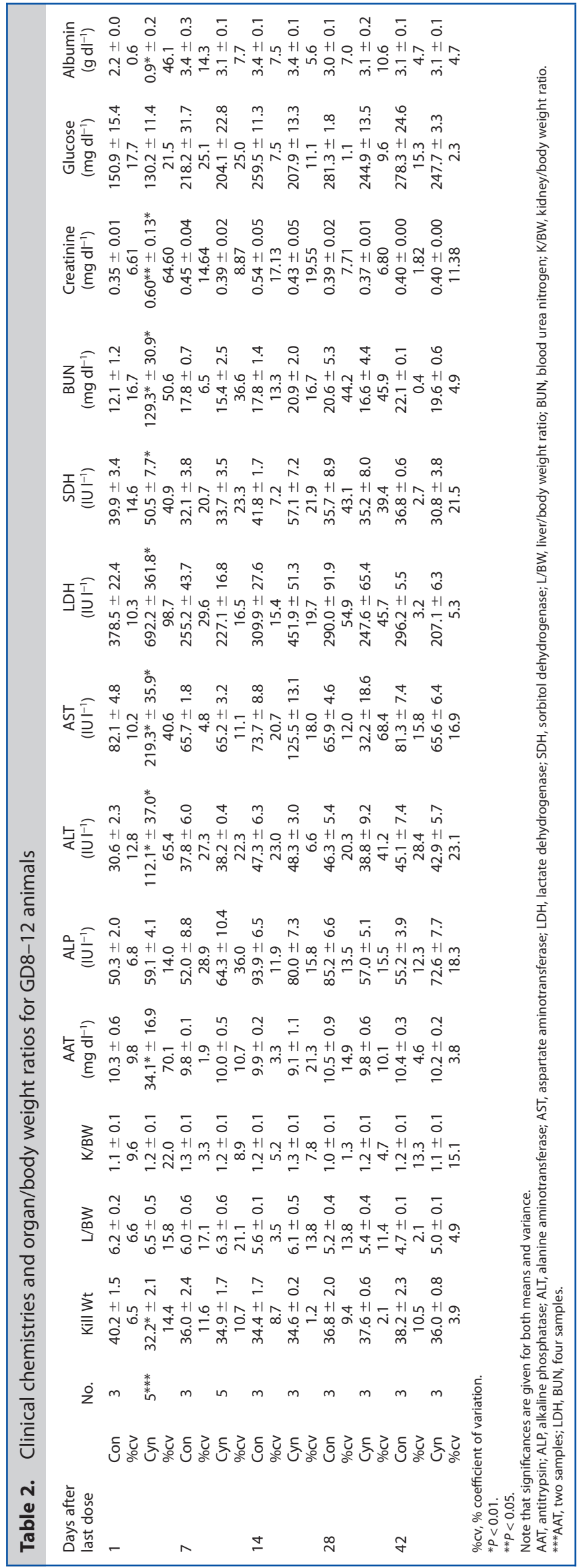

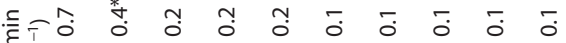

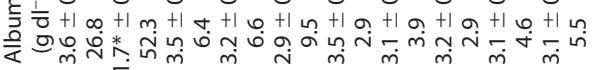

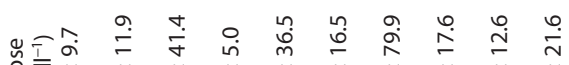
$0 \bar{z}+1 n+1$ n

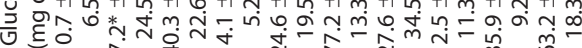

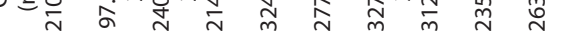

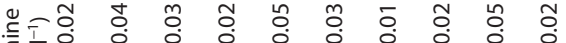

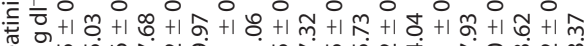

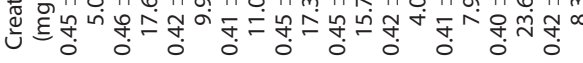

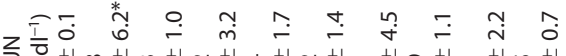

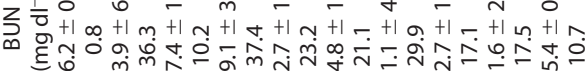

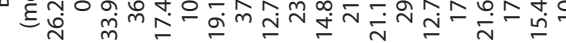

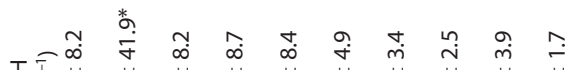

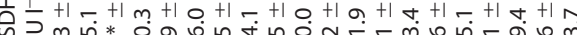

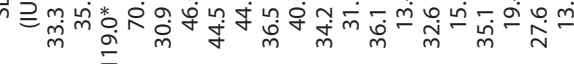

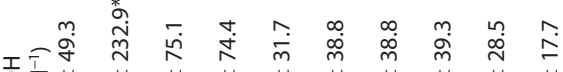

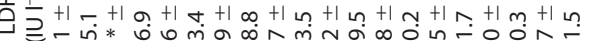
규

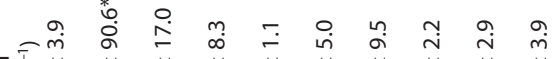

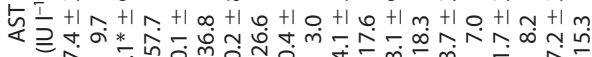

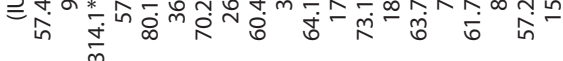

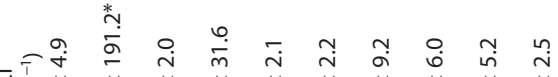

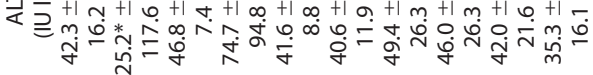

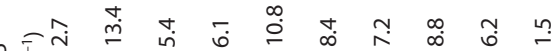

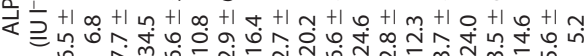

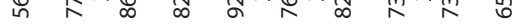

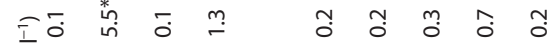

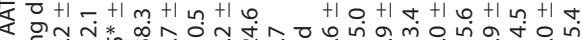

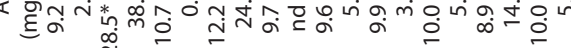

उ

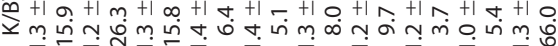

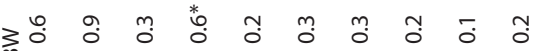

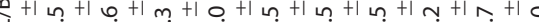

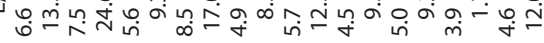

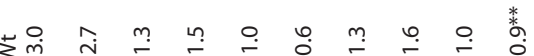

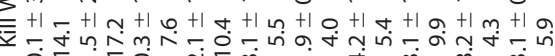

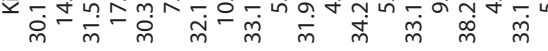
oे $v m$ in $m, n+m, m$

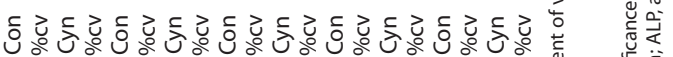
mi

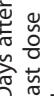

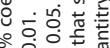

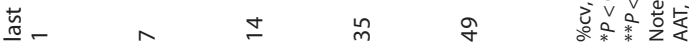


GD8-12 CYN-Exposed Animals

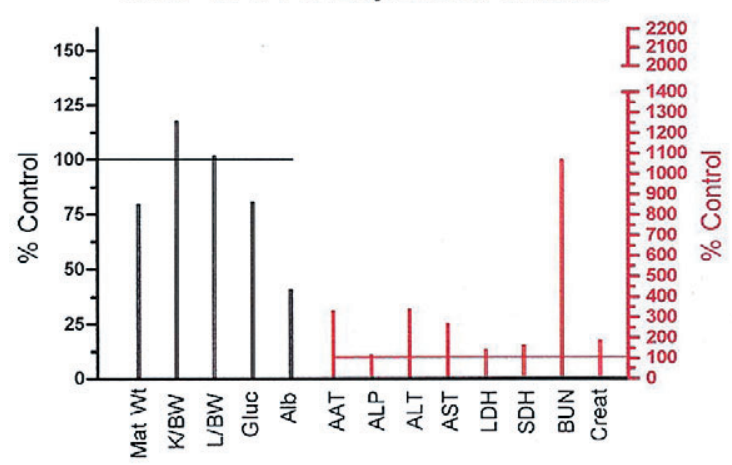

Animal \#121

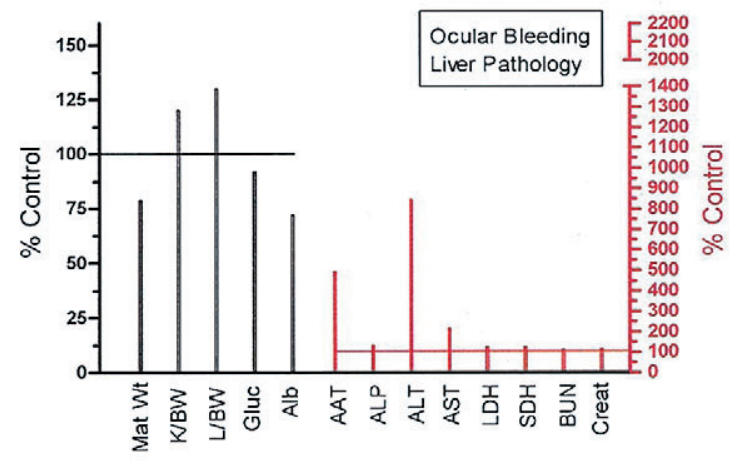

Animal \#120

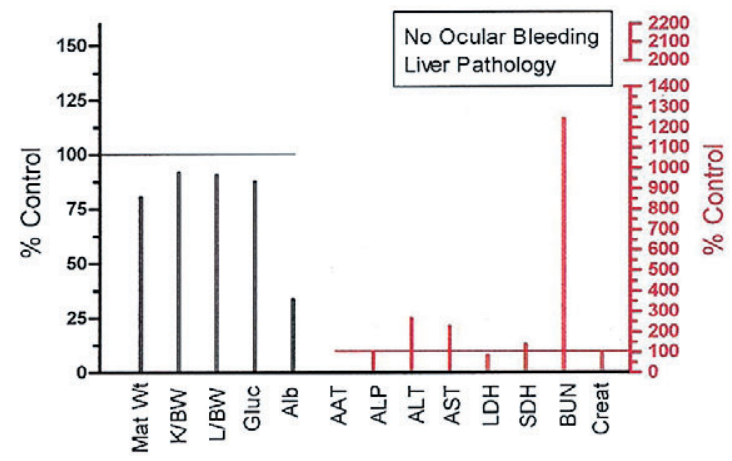

GD13-17 CYN-Exposed Animals

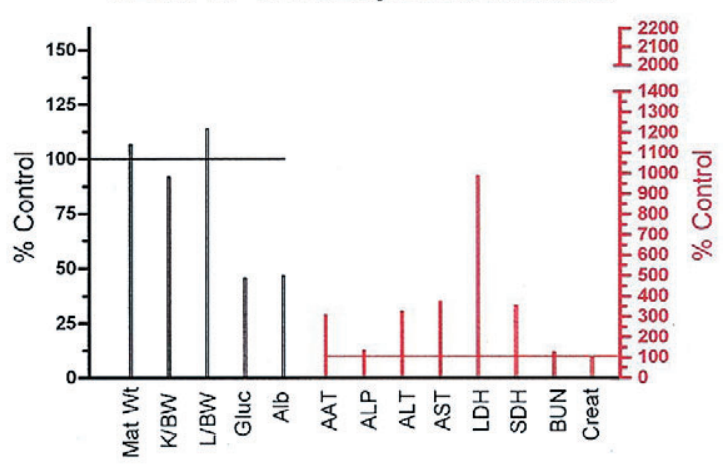

Animal \#29

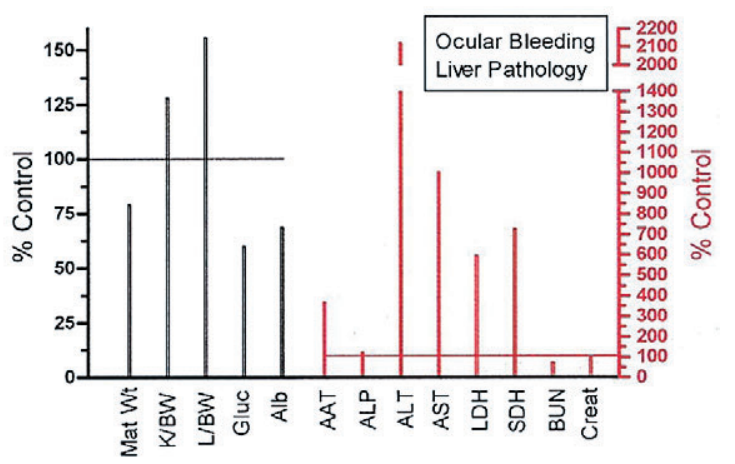

Animal \#69

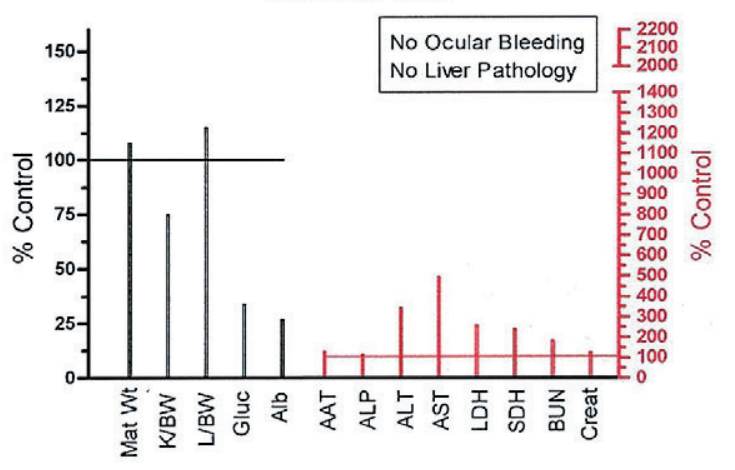

Figure 2. Toxicity profiles of averaged GD8-12 and GD13-17 animals' responses to CYN and individual animals within each of these dosing regimen groups. The left $y$-axis represents data on body and organ weights and general markers of metabolic homeostasis compared with control values (controls $=100 \%$ ). The right $y$-axis shows the degree of change in the hepatic and renal markers of toxicity as a percentage of the control values (controls $=100 \%)$.

and GD13-17 groups. LDH and SDH were significantly elevated $(P<0.01)$ in the GD13-17 group while showing a trend in the same direction in the GD8-12 group. At this time, serum albumin levels were significantly reduced $(P \leq 0.01)$ in both groups. One day after the last dose, both BUN $(P \leq 0.01)$ and creatinine $(P \leq 0.05)$ levels were significantly elevated in the GD8-12 group. Serum glucose levels were significantly lower $(P \leq 0.01)$ in the GD13-17 group while the serum glucose levels showed a trend in the same direction in the GD8-12 group. Values for clinical chemistries returned to normal 7 days after the last dose in both groups. No significant differences in kidney/body weight ratio were noted in either group. The liver/body weight ratio was not different in the GD8-12 group but were significantly elevated in the GD13-17 animals on day 7 post-dosing $(P<0.01)$ and remained higher than the control values for the remainder of the study.
Measures of variance (standard error) and variance relative to the mean (percentage coefficient of variation or \%cv) are listed in Tables 2 and 3. The variability in response across GD8-12 CYNexposed individuals was significantly greater one day after the last dose for serum levels of ALT, AST, LDH, SDH, BUN, creatinine and the kidney/body weight ratio $(P \leq 0.01)$. The response of the GD13-17 animals was generally similar with the following exceptions: the variance of AAT was significantly increased $(P \leq 0.01)$, as were the serum levels of albumin $(P \leq 0.01)$, but no significant effects were noted for either creatinine or kidney/body weight ratios.

An illustration of individual differences in response to CYN is shown in Fig. 2. This figure summarizes the GD8-12 and GD13-17 group'toxicity profiles' of weight changes and clinical chemistries as well as individual profiles of pairs of animals selected because 
Table 4. Incidence of histologic lesions in female mice treated with CYN either during GD8-12 or GD13-17

\begin{tabular}{|c|c|c|c|c|}
\hline \multirow[b]{2}{*}{ Dose in $\mu \mathrm{g} / \mathrm{kg}$} & \multicolumn{2}{|c|}{ GD8-12 } & \multicolumn{2}{|c|}{ GD13-17 } \\
\hline & 0 & 50 & 0 & 50 \\
\hline Hepatocyte necrosis ${ }^{a}$ & $1 / 9(11 \%)$ & $7 / 19(37 \%)$ & $1 / 9(11 \%)$ & $4 / 19(21 \%)$ \\
\hline Nephrosis and/or renal inflammation & $0 / 9$ & $5 / 19(26 \%)$ & $0 / 9$ & $0 / 19$ \\
\hline
\end{tabular}

of the range of responses they displayed. Although the type and the direction of changes induced by CYN were consistent, the degree of response varied considerably among animals. For example, in the GD13-17 animals illustrated, animals 29 and 69 differed from the group average. Animal 29 exhibited ocular bleeding, liver pathology, reduced body weight, increased liver/ body weight ratio and extremely high levels of hepatic toxicity markers, effects that were either absent or present to a much lesser degree in animal 69.

\section{Histopathology}

The incidence of histologic lesions is given in Table 4. Minimal to moderate centrilobular hepatocyte necrosis and apoptosis, primarily of scattered individual cells, were observed in 1/9 (11\%) of both GD8-12 and GD13-17 controls compared with 7/19 (37\%) GD8-12 and 4/19 (21\%) of GD13-17 CYN-exposed animals one day after the last dose. Scattered hepatocytes were either individually dying (via necrosis and/or apoptosis) or occasionally undergoing coagulative necrosis in groups, sometimes accompanied by varying degrees of inflammatory cell infiltrates (lymphocytes with occasional macrophages and neutrophils; Fig. 3). Lesions generally affected $<10 \%$ of the parenchyma. Minimal to moderate kidney lesions were noted only in 5/19 (26\%) treated GD8-12 dams. Affected animals had multifocal, minimal to moderate, chronic interstitial nephritis or minimal nephrosis seen as acute tubular epithelial necrosis (data not shown).

\section{Gene Array and Real-time PCR Analyses}

\section{Microarray analysis}

The transcriptional response to CYN was similar among individual animals and did not differ markedly across the two exposure groups. Canonical pathways or functional groups found to be altered by CYN one day following the last dose included ribosome biogenesis (Fig. 4), lipid metabolism (Fig. 5a), xenobiotic metabolism (Fig. 5b), the inflammatory response (Fig. 6a) and the nuclear factor E2-related factor 2 (Nrf2) response to oxidative stress (Fig. 6b).

\section{Real-time $q R T-P C R$ analysis}

The results for real-time quantitative RT-PCR are shown in Fig. 7. The genes chosen for PCR analysis represent a subset of genes shown by microarray analysis to be altered by CYN in the livers of the adult mice. A comparison of the microarray and RT-PCR data indicates that the direction of the gene expression changes was
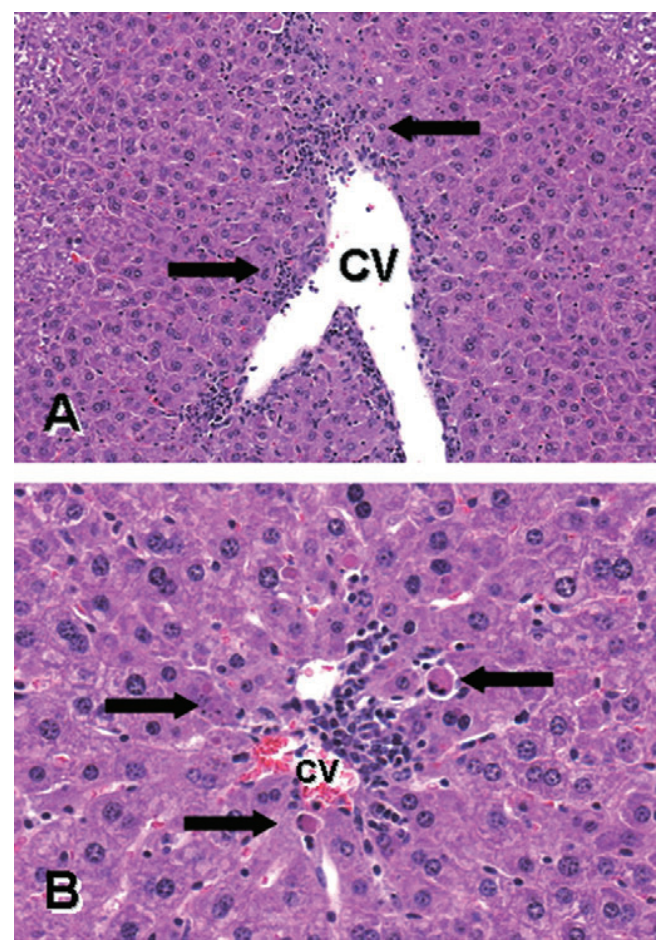

Figure 3. Photomicrographs of H\&E sections of liver from a mouse treated with $50 \mu \mathrm{g} \mathrm{kg}^{-1}$ of cylindrospermopsin during GD13-17 and killed on GD18, demonstrating centrilobular necrosis and apoptosis. The figures show different areas of the central vein (CV). Magnification is (A) $180 \times$ and (B) 380×. The arrows in (A) point to cell death and inflammation; arrows in $B$ point to apoptotic hepatocytes.

similar for most genes, although scattered differences in the degree of changes were observed in individual animals. Discrepancies were observed with regard to expression of Nrf2, especially among animals dosed on GD8-12. Increased expression of glutamate cysteine ligase (Gclc), a Nrf2 regulated gene (Wild et al., 1999; Han et al., 2008), was confirmed in all but one animal. Hepatic recovery from the changes induced by CYN was apparent as early as one week after dosing with expression levels close to control levels by post-dosing day 28 .

\section{DISCUSSION}

Cylindrospermopsin is a toxin that is produced by a variety of cyanobacterial species, especially C. raciborskii, which has been rapidly spreading globally and is now the source of many blooms worldwide. It has already been shown to have the potential to induce human toxicity via chlorinated drinking water. Surveys 


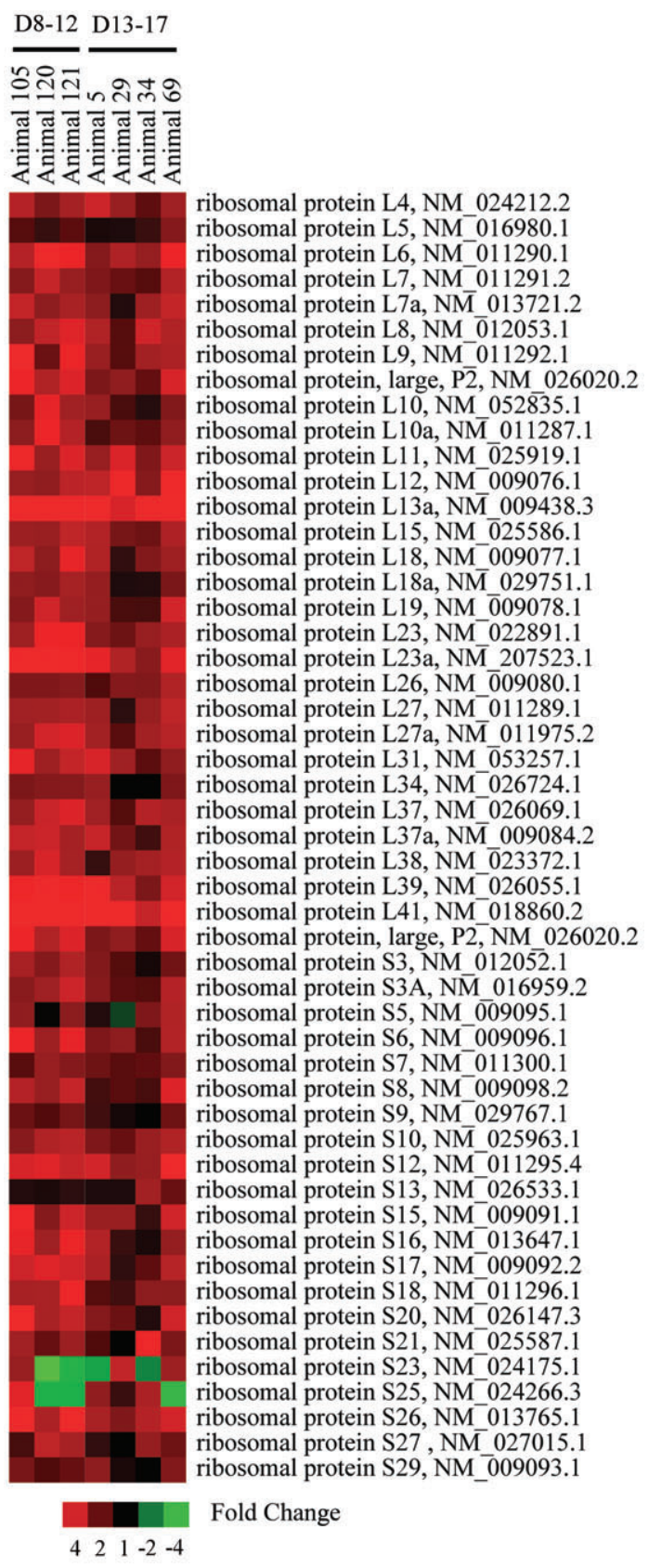

Figure 4. Effect of CYN on genes associated with ribosome. Many of the genes in this functional group were up-regulated by CYN in both dose groups. Red and green correspond to up- and down-regulation, respectively.

have identified blooms of $C$. raciborskii in Indiana (Jones and Sauter, 2005), Illinois (Holland et al., 2006) and Florida (Burns, 2008) in the USA. This organism also tends to decrease the biodiversity of phytoplankton species when it becomes established in a water system (Dobberfuhl, 2005). Increased dependence on surface waters for drinking coupled with climatic conditions that promote cyanobacterial growth make $C$. raciborskii an increasing threat to both the environment and human populations (Briand et al., 2004; Jones and Sauter, 2005; Burns, 2008).

Exposure of pregnant mice to CYN on GD8-12 induced greater toxicity than on GD13-17. Toxicity in GD8-12 animals was first noted as a significant reduction in weight gain after the initial dose that persisted throughout the dosing period. In contrast, there was no clear pattern of weight change in the GD13-17 dams. Mortality and vaginal bleeding occurred in 55 and $31 \%$ of the GD8-12 animals, respectively, vs 0\% in the GD13-17 group. The reason for these differences is unknown. If CYN is distributed across the fetal-maternal compartments, differences in maternal toxicity noted between treatment groups could be related to the changing volume of the embryo/fetal compartment during gestation. Although placental transfer studies of CYN have not been done, toxicity of CYN to pups exposed late in gestation (GD1317) indicates an absence of a placental barrier. The GD13-17 animals have a significantly larger fetal compartment and therefore the maternal exposure and associated toxicity would be much less at this time. In contrast, early in gestation the dose to the maternal organism exclusive of the embryo/fetus would be significantly higher and the resultant maternal toxicity greater.

The bleeding that occurred in treated animals is a relatively uncommon xenobiotic-induced effect. Hemorrhage in multiple sites in both the dam and fetus suggests a CYN-induced coagulopathy and/or vascular injury consistent with an alteration in coagulation factors and the coagulation cascade. Gene expression analysis indicated a down regulation of Coagulation Factor $X$. Deficiencies in the expression of this gene have been associated with bleeding in both humans (Peyvandi et al., 1998) and mice (Dewerchin et al., 2000), but a relationship to CYN-induced bleeding remains to be determined. Similar responses to CYN intoxication, i.e. bloody diarrhea and bleeding in the mucous membranes, were noted in affected humans (Byth, 1980). Protein synthesis inhibition is generally considered to be a key component of CYN-induced toxicity (Terao et al., 1994; Froscio et al., 2001, 2008; Metcalf et al., 2002; Neumann et al., 2007; Falconer, 2008). The degree to which such inhibition is responsible for CYN toxicity remains unknown. Froscio et al. (2003) failed to show a relation between the degree of protein synthesis inhibition in mouse hepatocytes and the leakage of LDH into the medium. They concluded that protein synthesis inhibition may not be fully responsible for CYN hepatocyte toxicity. Considerable cell proliferation in dermal and mouth epithelial layers of Bufo marinus tadpoles exhibiting CYN-induced toxicity was not consistent with general protein synthesis inhibition (Kinnear et al., 2007). The protein synthesis inhibitor, cycloheximide, does not induce liver necrosis (Farber, 1971) while others such as carbon tetrachloride (Smuckler et al., 1961) and galactosamine (Decker and Keppler, 1974) do result in hepatic necrosis. The bleeding that is a prominent characteristic of CYN toxicity has been reported after exposure to the protein synthesis inhibitor, $\mathrm{T}-2$, a fungal metabolite. Also, placental bleeding has been described in both rats (Doi et al., 2008) and mice (Schiefer, 1984; Rousseaux et al., 1986) exposed to T-2. This bleeding did not occur after the exposure to the protein synthesis inhibitor, emetine, but adverse clinical signs included vomiting and diarrhea (National Cancer Institute, 1978).

Hepatic toxicity was indicated by serum markers of liver function and histopathology. Elevations in AAT, ALP, ALT, AST, LDH and $\mathrm{SDH}$ indicated that the liver was adversely affected in both GD8-12 and GD13-17 dams one day after the last dose. Biochemical indicators of hepatic damage returned to normal after one week in the GD13-17 group and by 4 weeks in the GD8-12 animals. Reduction of serum albumin was also noted in both groups, indicating possible renal and/or hepatic injury. The hepatic histopathology consisted of centrilobular hepatocyte necrosis and was similar in both the GD8-12 and GD13-17 groups. These effects were not observed one week after dosing. 


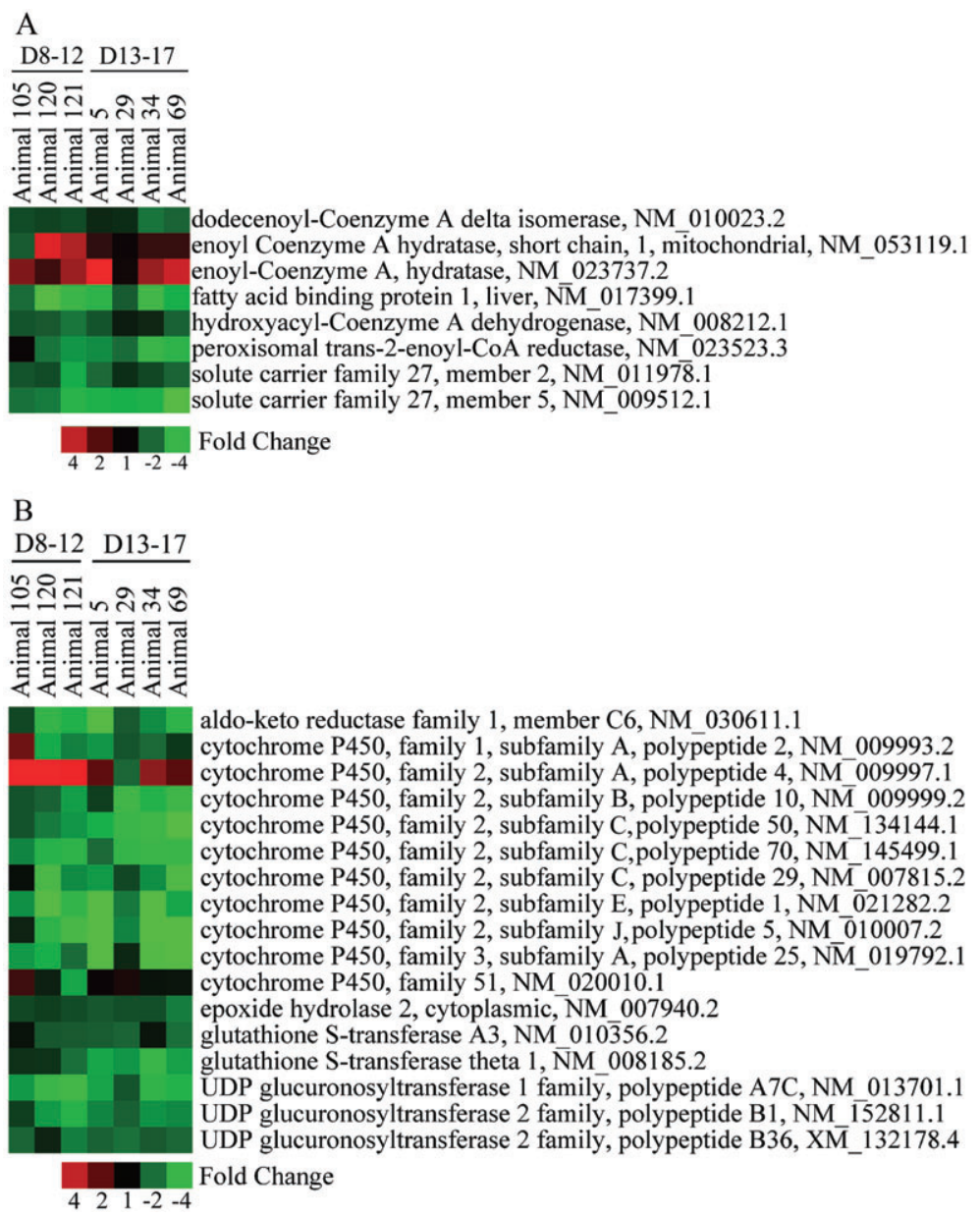

Figure 5. Effect of CYN on genes related to lipid metabolism (A) and xenobiotic metabolism (B). Genes in these functional categories showed uniform changes across animals in each treatment group, an effect consistent with hepatic injury. Red and green correspond to up- and down-regulation, respectively.

The liver has been described as a primary site of CYN-induced toxicity (Hawkins et al., 1985; Harada et al., 1994; Bernard et al., 2003; Griffiths and Saker, 2003; Terao et al., 1994). Our data do not necessarily support this hypothesis. Serum chemistries indicated similar hepatic toxicity in both treatment groups. However, five out of six serum markers indicative of hepatic toxicity showed greater changes from control values in the GD13-17 group, although significantly less lethality was seen in these animals. The incidence of hepatic histopathology was also similar in both groups but the severity of the changes was inconsistent with liver damage as a cause of death.

Markers for renal injury, BUN and creatinine, were increased in the GD8-12 but not in GD13-17 animals. Although these data are consistent with histopathological findings of renal tissue damage (nephrosis) in the GD8-12 group, it should be noted that the observed increase in BUN and disproportional slight increase in creatinine suggest that other possible sources, such as intraluminal hemorrhage, may have contributed to elevated BUN.

Similar changes in gene expression were observed in both dose groups when evaluated by microarray analysis $24 \mathrm{~h}$ after the final dose of CYN. These changes included altered expression of genes associated with ribosome biogenesis, lipid metabolism, xenobiotic metabolism, the inflammatory response and the Nrf2 response to oxidative stress. Transcriptional changes involving genes related to fatty acid metabolism and ribosome biogenesis were also reported by Chung et al. (2005) in the rat liver following a single toxic exposure to carbon tetrachloride, indicating that these changes may be common to hepatic injury. In addition, reduced cytochrome $\mathrm{P} 450$ enzyme activity and/or decreased expression of cytochrome P450 genes by specific inducers of liver inflammation has been described elsewhere (for reviews, see Gerrish and Malarkey, 2007; Renton, 2004; Morgan, 2001) and has previously been reported for CYN-exposed mice (Terao et al., 1994). Indeed, CYN is a known hepatotoxin (Seawright et al., 1999; Fastner et al., 2003; Terao et al., 1994) and while liver injury was apparent in the current study, the inability to draw a distinction between the two dose groups based on the gene expression data provides additional support to the argument that liver injury may not be the principal mode of action associated with the toxicity observed in CYN-expose mice. Additional studies using broad gene expression arrays at different time points following CYN exposure are currently underway and may provide a more complete understanding of the course of CYN-induced toxicity.

In recent years, there has been increased interest in identifying factors that are responsible for the range of responses observed within a population following exposure to a toxicant (see Fraser, 2004; Varki et al. 2008; Liao et al., 2008). Several investigators have noted the tendency of CYN to induce an unusually wide breadth 
A

D8-12 D13-17
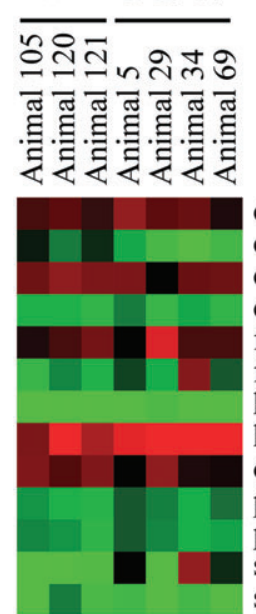

complement component 3, NM 009778.1

complement component $9, \mathrm{NM}^{-} 013485.1$

complement factor $\mathrm{H}, \mathrm{NM} 009 \overline{8} 88.2$

coagulation factor X, NM 007972.2

fibrinogen alpha chain, $N \bar{M} 010196.1$

fibrinogen beta chain, NM $\overline{1} 81849.1$

hepcidin antimicrobial peptide, NM_183257.1

hemopexin, NM 017371.1

orosomucoid 2, $\overline{\mathrm{N}} \mathrm{M}$ 008768.1

plasminogen, NM $0 \overline{0} 8877.2$

protein C, NM_0 $0 \overline{0} 934.1$

serpin peptidase inhibitor, clade A, member 1, NM 009246.1

serpin peptidase inhibitor, clade F, member 1, NM_011340.2

Fold Change

B

$\begin{array}{lllll}4 & 2 & 1 & -2 & -4\end{array}$

D8-12 D13-17
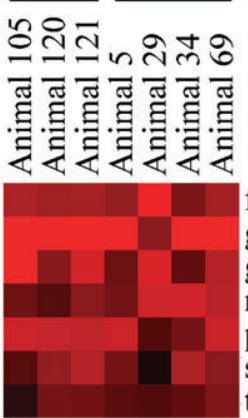

ferritin, heavy polypeptide 1 , NM 010239.1

glutamate-cysteine ligase, catalytic subunit, NM_010295.1

glutathione S-transferase M5, NM 010358.2

nuclear factor erythroid-derived 2-like 2, NM_010902.2

peroxiredoxin 1, NM 011034.2

sequestosome 1, NM-011018.1

thioredoxin, NM $01 \overline{1} 660.2$

$\begin{array}{lllll}4 & 2 & 1 & -2 & -4\end{array}$

Fold Change

Figure 6. Effect of CYN on genes associated with the inflammatory response (A) and the Nrf2 response to oxidative stress (B). Changes probably related to liver injury were observed across animals in each dose group. Red and green correspond to up- and down-regulation, respectively.

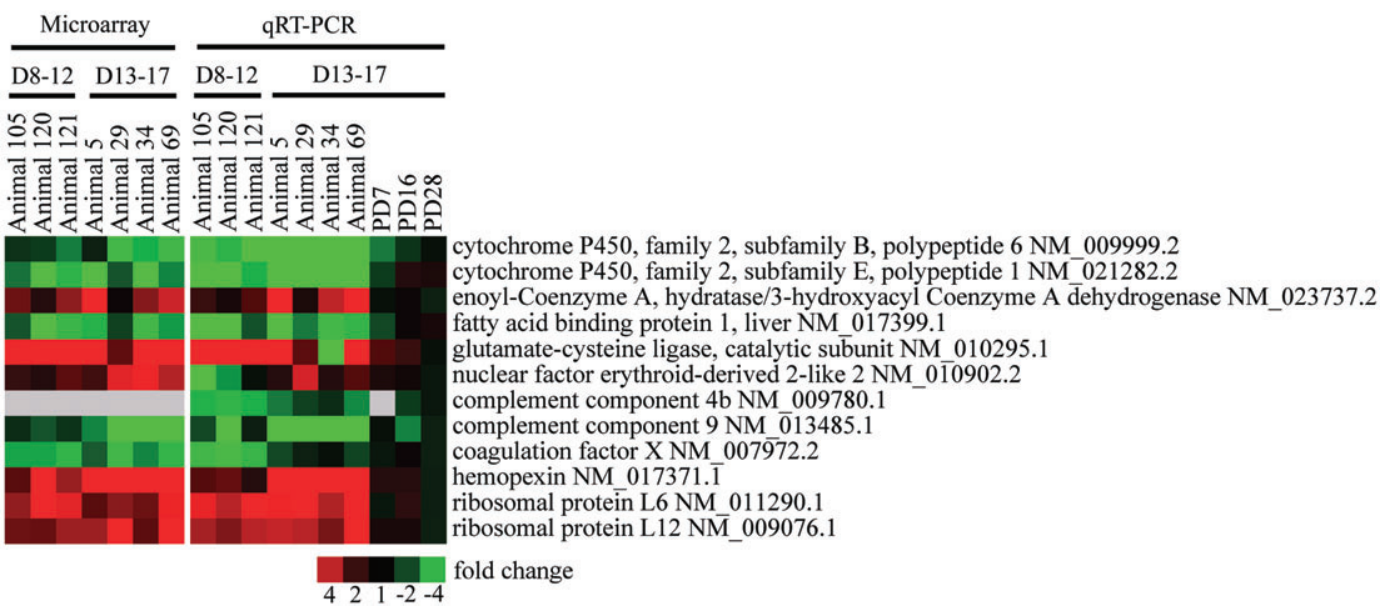

Figure 7. Real-time PCR evaluation of selected genes. Good agreement was found between the results from either microarray or RT-PCR analysis. Differences were observed with respect to expression of Nrf2, especially among animals dosed on GD8-12, although increased expression of glutamate cysteine ligase (Gclc), an Nrf2 regulated gene, was confirmed in all but one animal. Red and green correspond to up- and down-regulation, respectively. 
of individual responses to similar exposures in both mammals (Seawright et al., 1999; Norris et al., 2001a) and amphibians (White et al., 2007). The current study appears to support these observations. The degree of individual variability in response to specific toxicants is expressed by the standard error and the percentage coefficient of variation (\%cv) of the treatment groups. The significant increase in variance seen in the treated groups was evidence of the tendency of CYN to elicit a wide range of individual responses. The \%cv supports these observations in that the increase in variance relative to the mean is also highly noteworthy. The variance was significantly increased in both GD8-12 and GD13-17 groups for most of the hepatic toxicity measures. The variability in measures of renal function appeared to be greater in the GD8-12 group although serum BUN variability was also significantly elevated in the GD13-17 group.

The increasing global range of $C$. raciborskii, the identification of other cyanobacterial species that have been shown to be capable of producing CYN and the known adverse health impacts of exposure to CYN in humans and other mammalian species may be a cause for concern. Burns (2008) noted levels of CYN ranging from 8.1 to $97.1 \mu \mathrm{g} \mathrm{I}^{-1}$ in treated drinking water from Florida, an indication that that CYN may constitute a potential health risk in the USA. Therefore, there is a need for an increased research in numerous areas. The first, and arguably the most important, of these is a concerted effort to produce large quantities of well-characterized CYN or CYN-containing algal lyophilates so that the needed research can be undertaken in multiple laboratories. As long as CYN remains difficult to obtain, research efforts will be impeded. Research priorities should include: epidemiology studies to determine if there is an association between CYN in drinking water and adverse health effects similar to those noted in the 'Barcoo' disease of the Australia outback for which an association with CYN ingestion has been suggested (Cleland, 1911; Hayman, 1992); the identification of additional potential toxicants in C. raciborskii and active metabolites of CYN; the long-term effects of CYN exposure including potential carcinogenicity, immunotoxicity, adverse effects of prenatal exposure, CNS toxicity, reproductive impairment and organ toxicity; the course of CYN toxicity in the individual and the identification of the basal causes of the toxicity; the environmental effects of the spread of $C$. raciborskii; and the environmental conditions that determine the amounts of CYN produced in blooms and the retention of the CYN in bodies of water.

The study reported here was designed to make a thorough assessment of the impact of CYN administered to adult mice by i.p. injection during either early (GD8-12) or late (GD13-17) gestation and the subsequent recovery from the induced toxicity. A range of endpoints including clinical observations, gross and microscopic pathology, serum biochemistry and hepatic gene expression were evaluated. The exposed animals exhibited toxic effects similar to those described in a human population (Palm Island, Australia) exposed to CYN via chlorinated drinking water, that is, gastrointestinal bleeding and hepatic and renal toxicity. The similarity in response demonstrates that i.p. administration of CYN in mice is a valid model for CYN-induced toxicity in humans. The data indicate a significant variability in individual responses to CYN intoxication. Evidence of a return to normalcy was noted by PD7 with a small number of exceptions. One week after dosing, gastrointestinal bleeding was observed in a single GD13-17 CYN-exposed animal and elevated liver/body weight ratios were seen in the same dose group. Recovery appeared to be complete at time points examined after 2 weeks post-dosing.
A comparable rate of recovery was also noted for most genes evaluated by RT-PCR although changes in the expression of specific genes (e.g. Gclc and hemopexin) persisted for up to 2 weeks post-dosing. All gene expression levels had returned to normal values by 4 weeks post-dosing.

\section{Acknowledgments}

We would like to thank Dr Carin Vanderklok, North Carolina State University School of Veterinary Medicine for assistance with the histological analyses. The information in this document has been funded by the US Environmental Protection Agency. It has been subject to review by the National Health and Environmental Effects Research Laboratory and approved for publication. Approval does not signify that the contents reflect the views of the Agency, nor does mention of trade names or commercial products constitute endorsement or recommendation for use. Drs Bradfield and Liu are supported by NIH grant numbers ES012752 and CA014520. The histological analysis was supported by the Intramural Research Program of the NIH, National Institute of Environmental Health Sciences.

\section{REFERENCES}

Bain P, Shaw G, Patel B. 2007. Induction of p53-regulated gene expression in human cell lines exposed to the cyanobacterial toxin Cylindrospermopsin. J. Toxicol. Environ. Health, Pt A 70: 1687-1693.

Banker R, Carmeli S, Hadas O, Teltsch B, Porat R, Sukenik A. 1997. Identification of cylindrospermopsin in Aphanizomenon ovalisporum (Cyanophyceae) isolated from Lake Kinneret, Israel. Journal of Phycology 33: 613-616.

Bernard C, Harvey M, Briand JF, Bire R, Krys S, Fontaine JJ. 2003. Toxicological comparison of diverse Cylindrospermopsis raciborskii strains: evidence of liver damage caused by a French C. raciborskii strain. Environmental Toxicology 18: 176-186.

Bourke ATC, Hawes RB, Neilson A, Stallman ND. 1983. An outbreak of hepato-enteritis (the Palm Island mystery disease) possibly caused by algal intoxication. Toxicon Supplement 3: 45-48.

Box GEP and Cox DR. 1964 An analysis of transformations. J. R. Stat. Soc., Ser. B (Methodol.) 26: 211-252.

Briand J-F, Leboulanger C, Humbert J-F, Bernard C, Dufour P. 2004. Cylindrospermopsis raciborskii (Cyanobacteria) invasion at mid-latitudes: selection, wide physiological tolerance, or global warming? Journal of Phycology 40: 231-238.

Burns J. 2008. Toxic cyanobacteria in Florida waters. In Cyanobacterial Harmful Algal Blooms: State of the Science and Research Needs, Advances in Experimental Medicine and Biology, Vol. 619, Hudnell HK (ed.). Springer: New York; 127-138.

Byth S. 1980. Palm Island mystery disease. Med. J. Aust. 2: 40-42.

Chernoff N, Hunter ES, Hall LL, Rosen MB, Brownie CF, Malarkey D, Marr M, Herkovits J. 2002. Lack of teratogenicity of microcystin-LR in the mouse and toad. J. Appl. Toxicol. 22: 13-17.

Chung H, Hong DP, Jung JY, Kim HJ, Jang KS, Sheen YY, Ahn Jl, Lee YS, Kong G. 2005. Comprehensive analysis of differential gene expression profiles on carbon tetrachloride-induced rat liver injury and regeneration. Toxicol. Appl. Pharmacol. 206: 27-42.

Cleland JB. 1911. Some diseases peculiar to, or of interest in, Australia. J. Univ. Sydney Med. Soc. 4: 29-48.

Decker K, Keppler D. 1974. Galactosamine hepatitis: Key role of the nucleotide deficiency period in the pathogenesis of cell injury and cell death. Pharmacol. Rev. Physiol. Biochem. 71: 77-106.

Dewerchin M, Liang Z, Moons L, Carmeliet P, Castellino FJ, Collen D, Rosen ED. 2000. Blood coagulation factor $X$ deficiency causes partial embryonic lethality and fatal neonatal bleeding in mice. Thromb. Haemost. 83: $185-190$.

Dobberfuhl DR. 2005. Cylindrospermopsis raciborskii in three central Florida lakes: population dynamics, controls, and management implications. Lake and Reservoir Management 19: 341-348.

Doi K, Ishigami N, Sehata S. 2008. T-2 toxin-induced toxicity in pregnant mice ant rats. Int. J. Mol. Sci. 9: 2146-2158. 
Falconer I. 2008. Health effects associated with controlled exposures to cyanobacterial toxins. Adv. Exp. Med. Biol. 619: 607-612.

Falconer IR, Hardy SJ, Humpage AR, Froscio SM, Tozer GJ, Hawkins PR. 1999. Hepatic and renal toxicity of the blue-green alga (Cyanobacterium) Cylindrospermopsis raciborskii in male Swiss Albino mice. Environ. Toxicol. 14: 143-150.

Farber E. 1971. Biochemical pathology. Annu. Rev. Pharacol. 11: 71-96.

Fastner J, Heinze R, Humpage AR, Mischke U, Eaglesham GK, Chorus I. 2003. Cylindrospermopsin occurrence in two German lakes and preliminary assessment of toxicity and toxin production of Cylindrospermopsis raciborskii (Cyanobacteria) isolates. Toxicon 42: 313-321.

Fergusson KM, Saint CP. 2003. Multiplex PCR assay for Cylindrospermopsis raciborskii and cylindrospermopsin-producing cyanobacteria. Environ. Toxicol. 18: 120-125.

Fraser CG. 2004. Inherent biological variation and reference values. Clin. Chem. Lab. Med. 42: 758-764.

Froscio SM, Humpage AR, Burcham PC, Falconer IR. 2001. Cell-free protein synthesis inhibition assay for the cyanobacterial toxin Cylindrospermopsin. Environ. Toxicol. 16: 408-412.

Froscio SM, Humpage AR, Burcham PC, Falconer IR. 2003. Cylindrospermopsin-induced protein synthesis inhibition and its dissociation from acute toxicity in mouse hepatocytes. Environ. Toxicol. 18: $243-251$.

Froscio SM, Humpage AR, Wickramasinghe W, Shaw G, Falconer IR. 2008. Interaction of the cyanobacterial toxin Cylindrospermopsin with the eukaryotic protein synthesis system. Toxicon 51: 191-198.

Gerrish K, Malarkey DE. 2007. Genomic profiles of liver injury. In Hepatotoxicity: From Genomics to In-vitro and In-Vivo, Sahu S (ed.). Wiley: New York; 466-488.

Griffiths DJ, Saker ML. 2003. The Palm Island Mystery Disease 20 years on: a review of research on the cyanotoxin cylindrospermopsin. Environ. Toxicol. 18: 78-93.

Han ES, Muller FL, Perez VI, Qi W, Liang H, Xi L, Fu C, Doyle E, Hickey M, Cornell J, Epstein CJ, Roberts LJ, Van Remmen H and Richardson A. 2008. The in vivo gene expression signature of oxidative stress. Physiol Genomics 34: 112-26.

Harada K-I, Ohtani I, Iwamoto K, Suzuki M, Watanabe MF, Watanabe M, Terao K. 1994. Isolation of cylindrospermopsin from a cyanobacterium Umezakia natans and its screening method. Toxicon 32: 73-84.

Hawkins PR, Runnegar MTC, Jackson ARB, Falconer IR. 1985. Severe hepatotoxicity caused by the tropical cyanobacterium (blue-green alga) Cylindrospermopsis raciborskii (Woloszynska) Seenaya and Subba Raju isolated from a domestic supply reservoir. Appl. Environ. Microbiol. 50: 1292-1295.

Hayes KR, Vollrath AL, Zastrow GM, McMillan BJ, Craven M, Jovanovich S, Rank DR, Penn S, Walisser A, Reddy JK, Thomas RS, Bradfield CA. 2005. EDGE: a centralized resource for the comparison, analysis and distribution of toxicogenomic information. Mol. Pharmacol. 67: 13601368.

Hayman J. 1992. Beyond the Barcoo - probable human tropical cyanobacterial poisoning in outback Australia. Med. J. Australia 157: 794796.

Holland T, St. Amand A, Good G. 2006. Otter Lake '05 - a successful response to a potentially toxic Cylindrospermopsis raciborskii bloom. Lakeline 26: 52-56.

Humpage AR, Falconer IR. 2003. Oral toxicity of the cyanobacterial toxin cylindrospermopsin in male Swiss Albino Mice: determination of no observed adverse effect level for deriving a drinking water guideline value. Environ. Toxicol. 18: 94-103.

Humpage AR, Fontaine F, Froscio S, Burcham P, Falconer IR. 2005. Cylindrospermopsin genotoxicity and cytotoxicity: role of cytochrome P-450 and oxidative stress. J. Toxicol. Environ. HIth A 68: 739-753.

Jones WW, Sauter S. 2005. Distibution and abundance of C. raciborskii in Indiana Lakes and reservoirs. School of Public and Environmental Affairs, Indiana University. http://www.spea.indiana.edu/clp/ FinalCylindro\%20Web.pdf

Kinnear SWH, Fabbro LD, Duivenvoorden LJ, Hibberd EMA. 2007. Multiple-organ toxicity resulting from Cylindrospermopsin exposure in tadpoles of the cane toad (Bufo marinus). Environ. Toxicol. 22: 550558.

Kinnear SHW, Duivenvoorden LJ, Fabbro LD. 2009. Ecotoxicity and bioaccumulation from Cylindrospermopsis raciborskii: towards the development of environmental protection guidelines for contaminated water bodies. In Lake Pollution Research Progress, Miranda FR, Bernard LM (eds). Nova Science: New York; 81-106.
Levene H. 1960. Robust tests for equality of variances. In Contributions to Probability and Statistics: Essays in Honor of Harold Hotelling, Olkin I et al. (eds). Stanford University Press: Stanford, CA; 278-292.

Li R, Carmichael WW, Brittain S, Eaglesham GK, Shaw GR, Noparatnaraporn AMN, Yongmanitchai W, Kaya K, Watanabe MM. 2001 a. Detection of cylindrospermopsin from a strain of Cylindrospermopsis raciborskii (Cyanobacteria) isolated from Thailand. Toxicon 39: 973980.

Li R, Carmichael WW, Brittain S, Eaglesham GK, Shaw GR, Liu YK, Watanabe MM. 2001b. First report of the cyanotoxin cylindrospermopsin and deoxycylindrospermopsin from Raphidiopsis curvata (cyanobacteria). Journal of Phycology 37: 1121-1126.

Liao G, Zhang X, Clark DJ, Peltz G. 2008. A genomic 'roadmap' to 'better' drugs. Drug Metab. Rev. 40: 225-239.

Livak KJ, Schmittgen TD. 2001. Analysis of relative gene expression data using real-time quantitative PCR and the $2-\Delta \Delta C T$ method. Methods 25: 402-408.

Metcalf JS, Lindsay J, Beattie KA, Birmingham S, Saker ML, Torokne AK, Codd GA. 2002. Toxicity of cylindrospermopsin to the brine shrimp Artemia salina: comparisons with protein synthesis inhibitors and microcystins. Toxicon 40: 1115-1120.

Morgan ET. 2001. Regulation of cytochrome p450 by inflammatory mediators: why and how? Drug Metab. Dispos. 29: 207-212.

National Cancer Institute. 1978. Bioassay of emetine for possible carcinogenicity. Carcinogenesis Technical Report Series No. 43.

National Research Council. 1996. Guide for the Care and Use of Laboratory Animals. National Academy Press, Washington, DC.

Neumann C, Bain P, Shaw G. 2007. Studies of the comparative in vitro toxicology of the cyanobacterial metabolite deoxycylindrospermopsin. J. Toxicol. Env. Health 70: 1679-1686.

Norris RL, Seawright AA, Shaw GR, Smith MJ, Chiswell RK, Moore MR. 2001a. Distribution of ${ }^{14} \mathrm{C}$ cylindrospermopsin in vivo in the mouse. Environ. Toxicol. 16: 498-505.

Norris RL, Eaglesham GK, Shaw GR, Senogles P, Chiswell RK, Smith MJ, Davis BC, Seawright AA, Moore MR. 2001b. Extraction and purification of the zwitterions cylindrospermopsin and deoxycylindrospermopsin from Cylindrospermopsis raciborskii. Environ. Toxicol. 16: 391-396.

Norris RL, Seawright AA, Shaw GR, Senogles P, Eaglesham GK, Smith MJ, Chiswell RK, Moore MR. 2002. Hepatic xenobiotic metabolism of cylindrospermopsin in vivo in the mouse. Toxicon 40: 471-476.

Ohtani I, Moore RE, Runnegar MTC. 1992. Cylindrospermopsin, a potent hepatotoxin from the blue-green alga Cylindrospermopsis raciborskii. Journal of the American Chemical Society 114: 7941-7942.

Peyvandi F, Mannucci PM, Lak M, Abdoullah M, Zeinali S, Sharifian R, Perry D. 1998. Congenital factor $X$ deficiency: spectrum of bleeding symptoms in 32 Iranian patients. Br. J. Haematol. 102: 626-628.

Preussel K, Stuken A, Wiedner C, Chorus I, Fastner J. 2006. First report of cylindrospermopsin producing Aphanizomenon flos-aquae (Cyanobacteria) isolated from two German lakes. Toxicon 47: 156-162.

Renton KW. 2004. Cytochrome P450 regulation and drug biotransformation during inflammation and infection. Curr. Drug Metab. 5: 235243.

Rogers EH, Hunter ES, Moser VC, Phillips PM, Herkovits J, Munoz L, Hall LL, Chernoff N. 2005. Potential developmental toxicity of anatoxin-a, a cyanobacterial toxin. J. Appl. Toxicol. 25: 527-534.

Rogers EH, Zehr RD, Gage MI, Humpage AR, Falconer IR, Marr M, Chernoff N. 2007. The cyanobacterial toxin, cylindrospermopsin, induces fetal toxicity in the mouse after exposure late in gestation. Toxicon 49: 855-864.

Rousseaux CG, Schiefer HB, Hancock DS. 1986. Reproductive and teratological effects of continuous low level dietary T-2 toxin in female CD-1 mice for two generations. J. Appl. Toxicol. 6: 179-184.

Runnegar MT, Kong S-M, Zhong Y-Z, Lu SC. 1995. Inhibition of reduced glutathione synthesis by cyanobacterial alkaloid cyliondrospermopsin in cultured rat hepatocytes. Biochem. Pharmacol. 49: 219-225.

Saker ML, Thomas AD, Norton JH. 1999. Cattle mortality attributed to the toxic cyanobacterium Cylindrospermopsis raciborskii in an outback region of north Queensland. Environ. Toxicol. 14: 179-182.

Saker ML, Nogueira IC, Vasconcelos VM, Neilan BA, Eaglesham GK, Pereira P. 2003. First report and toxicological assessment of the cyanobacterium Cylindrospermopsis raciborskii from Portuguese freshwaters. Ecotoxicol. Environ. Safety 55: 243-250.

SAS Institute Inc. 2008. SAS/STAT 9.2 User's Guide. Cary, NC.

Schiefer HB. 1984. Lethal hemorrhages in pregnant mice following one oral dose of T-2 toxin. Arch. Belg. Suppl. 252-253. 
Seawright AA, Nolan CC, Shaw GR, Chiswell RK, Norris RL, Moore MR, Smith MJ. 1999. The oral toxicity for mice of the tropical cyanobacterium Cylindrospermopsis raciborskii (Woloszynska). Environ. Toxicol. 14: 135-142.

Smuckler EA, Iseri OA, Benditt EP. 1961. Studies on carbon tetrachloride intoxication. I. The effect of carbon tetrachloride on incorporation of labeled amino acids into plasma proteins. Biochem. Biophys. Res. Commun. 5: 270-275.

Sterling DJ, Quilliam MA. 2001. First report of the cyanobacterial toxin cylindrospermopsin in New Zealand. Toxicon 39: 1219-1222.

Terao K, Ohmori S, Igarashi K, Ohtani I, Watanabe MF, Harada KI, Ito E, Watanabe M. 1994. Electron microscopic studies on experimental poisoning in mice induced by cylindrospermopsin isolated from bluegreen alga Umezakia natans. Toxicon 32: 833-843.

Thomas AD, Saker ML, Norton JH, Olsen RD. 1998. Cyanobacterium Cylindrospermopsis raciborskii as a probable cause of death in cattle in northern Queensland. Aust. Vet. J. 76: 592-594.
Varki A, Geschwind DH, Eichler EE. 2008. Explaining human uniqueness: genomic interaction with environment, behavior and culture. Nat. Rev. Genet. 9: 749-763.

White SH, Duivenvoorden LJ, Fabbro LD, Eaglesham GK. 2006. Influence of intracellular toxin concentrations on cylindrospermopsin bioaccumulation in a fresh water gastropod (Melanoides tuberculata). Toxicon 47: 497-509.

White SH, Duivenvoorden LJ, Fabbro LD, Eaglesham GK. 2007. Mortality and toxin bioaccumulation in Bufo marinus following exposure to Cylindrospermopsis raciborskii cell extracts and live cultures. Environ. Pollut. 147: 158-167.

Wild AC, Moinova HR, and Mulcahy RT. 1999. Regulation of gammaglutamylcysteine synthetase subunit gene expression by the transcription factor Nrf2. J. Biol. Chem. 274: 33627-33636. 